\title{
Karyological studies in Brazilian species of Lippia L. (Verbenaceae)
}

\author{
SAULO M. SOUSA ${ }^{1}$, GIOVANA A. TORRES ${ }^{2}$ and LYDERSON F. VICCINI ${ }^{1}$ \\ ${ }^{1}$ Instituto de Ciências Biológicas, Departamento de Biologia, Universidade Federal de Juiz de Fora, \\ Campus Universitário, Rua José Lourenço Kelmer, s/n, Bairro São Pedro, 36036-900 Juiz de Fora, MG, Brasil \\ ${ }^{2}$ Departamento de Biologia, Universidade Federal de Lavras (UFLA), Caixa Postal 3037 , \\ Campus Universitário, 37200-000 Lavras, MG, Brasil
}

Manuscript received on September 15, 2011; accepted for publication on November 14, 2011

\begin{abstract}
The genus Lippia (Verbenaceae) comprise around 160 species spread out mainly in South and Central Americas with few African species, some of them with potential medicinal use. Brazil is one the most important centers of diversity with approximately $75 \%$ of the species described so far. Innumerous species are endemic and poorly studied especially at a cytological level. Here, chromosomal length, karyomorphology and chromosome asymmetry of twelve Brazilian species of Lippia were evaluated [L. alba (Miller) N.E.Brown, L. diamantinensis Glaz., L. florida Cham., L. hermanioides Cham., L. lacunosa Mart. \& Schauer, L. lupulina Cham., L. pohliana Schauer, L. pseudothea (St. Hil) Schauer, L. rosella Moldenke, L. rotundifolia Cham., L. rubella Moldenke and $L$. sidoides Cham.]. The analysis suggested that the genus has a variable chromosome number (from $2 n=20$ to $2 n=56$ ) originated by dysploidy and polyploidy. This is the first description of chromosome morphology for 11 of the 12 Lippia species studied.
\end{abstract}

Key words: chromosomes, cytology, dysploidy, karyology, Lippia, polyploidy.

\section{INTRODUCTION}

Cytogenetic studies have long been contributing to increase evolutionary, phylogenetic and taxonomic inferences about various plant groups (Stebbins 1971, Pellicer et al. 2007, Guerra 2008, Kissling et al. 2008). The karyotype can be considered as the phenotypic aspect of the chromosome complement at mitotic metaphase. For several decades, it was the prime cytological trait used to infer species relationships (Levin 2002). In a general way, the description of the karyotype includes: the chromosome number, the total length of chromosome complement (genome size), the

Correspondence to: Saulo Marçal de Sousa

E-mail: saulo_marcal@yahoo.com.br absolute and relative size of chromosomes, the symmetry of each chromosome (as dictated by the position of the centromere on each chromosome), the number and positions of satellites associated with the nucleolar-organizing regions and the distribution of heterochromatin segments. In addition, modern molecular cytogenetic techniques, as FISH (Fluorescent in situ Hybridization) and GISH (Genome in situ hybridization) permit the mapping of specific sequences in chromosomes and the study of genome constitution, respectively (Levin 2002, Guerra 2008).

Very often chromosome number variation has been used to understand karyoptype evolution and three basic mechanisms could be suggested to explain those variations at genus level. Polyploidization is 
one the most important mechanisms of angiosperms evolution, probably due to the success of the hybrids comparing with their diploids parents (Stebbins 1971, Ramsey and Schemske 1998, Guerra 2008, Soltis et al. 2009). Another possible mechanism that is not a consensus as an important evolutionary event is aneuploidy. According to Guerra (2008), mainly due to the induction of lethality or subvitality, this kind of chromosome variation has apparently no evolutionary meaning and has been largely documented in cultivated plants and in human chromosome disorders. Besides, aneuploidy in natural plant populations occurs in isolated individuals, asexual clones, cryptic species, interespecific hybrids, B chromosomes or any particular mechanism, but not as a general event. The third mechanism, the dysploidy, in contrast to polyploidy, induces an alteration on the average length of the chromosomes, altering (when structural changes occur) or not the total chromosome length (Jones 1998, Guerra 2008).

Lippia L., an important genus of the Verbenaceae family, possesses many species mainly distributed throughout South and Central America and Tropical Africa. Brazil, one of the most important centers of diversity possesses nearly $75 \%$ of the 160 described species that can be easily found in Brazilian rocks environments with high altitudes (Salimena 2000, Viccini et al. 2006). Although many species have been considered as an important source of chemical constituents for pharmaceutical, food and cosmetic industry, few studies have been done in order to amplify their biological, anatomical, morphological, physiological, phenological, genetic and evolutionary knowledge (Salimena 2000, Pascual et al. 2001, Viccini et al. 2006, Sousa et al. 2009, Campos et al. 2011).

Few studies have been done about the karyology of the genus Lippia. Most of them only reported the chromosome numbers (Bose and Choudhury 1960, Smith 1966, Navaneethan 1982, Coleman 1982, Filippa 1984, Kumar and Dutt 1989, Brandão et al. 2005, Viccini et al. 2006, Campos et al. 2011).
Moreover, the authors used mainly meiotic and nonmitotic chromosomes, due to the difficult of obtaining meristematic roots (Viccini et al. 2006, Campos et al. 2011). The chromosome number described for the genus vary from $\mathrm{n}=10$ for L. rubella (Viccini et al. 2006) to $\mathrm{n}=30$ for L. turbinata and L. fissicalyx (Pastoriza and Andrada 2006). Studies with somatic chromosomes were done only for $L$. turbinata, $L$. fissicalyx (Pastoriza and Andrada 2006) and Lippia alba (Brandão et al. 2007, Sousa et al. 2009, Pierre et al. 2011). For L. alba, the most studied species, the karyological studies reveal the centromer position, number of secondary constrictions, heterochromatin distribution and the map of rDNA sites (45S and 5S) by FISH (Brandão et al. 2007, Sousa et al. 2009). More yet, Pierre et al. (2011) related intraspecific chromosome number showing polyploidy and mixoploidy for different accessions of $L$. alba .

Considering the small number of species karyomorphologically studied in Lippia, the present paper reports karyomorphological aspects of twelve Brazilian species of Lippia, with eleven of them studied for the first time.

\section{MATERIALS AND METHODS}

Plant materials. All species were collected at Espinhaço Range of Minas Gerais state (MG), Brazil. Only L. alba was collected directly from the germplasm collection of Universidade Federal de Juiz de Fora, Minas Gerais, Brazil. The collection data and Voucher number of each species are described in Table I. The Vouchers are deposited at the Herbarium CESJ of Universidade Federal de Juiz de Fora. Approximately three individuals were analyzed per species.

Chromosome preparation. Meristematic cells from root tips and apical buds meristems were pretreated with 8-hydroxyquinoline ( 2 and $3 \mathrm{mM}$ ) during $6-14 \mathrm{~h}$ at $4^{\circ} \mathrm{C}$ and fixed in 3:1 methanol: acetic acid solution for at least $24 \mathrm{~h}$ before the slide preparation.

Slide preparation (root meristems). Pre-treated root tips were macerated in an enzymatic solution 
TABLE I

Collection data of Lippia species from Espinhaço Range, Minas Gerais (MG) State, Southeast, Brazil.

\begin{tabular}{|c|c|c|c|c|}
\hline Species & Origin Place & Latitude & Longitude & Herbarium number \\
\hline Lippia alba (Miller) N.E. Brown & Juiz de Fora-MG & $21^{\circ} 23^{\prime} 21^{\prime \prime} \mathrm{S}$ & $42^{\circ} 41^{\prime} 48^{\prime \prime} \mathrm{W}$ & 47,724 \\
\hline Lippia diamantinensis Glaz. & Diamantina-MG & $18^{\circ} 14^{\prime} 48^{\prime \prime} \mathrm{S}$ & $43^{\circ} 36^{\prime} 6^{\prime \prime} \mathrm{W}$ & 34,734 \\
\hline Lippia florida Cham. & Diamantina-MG & $18^{\circ} 14^{\prime} 48^{\prime \prime S}$ & $43^{\circ} 36^{\prime} 6^{\prime \prime} \mathrm{W}$ & 34,738 \\
\hline Lippia hermanioides Cham. & Serra do Cipó-MG & $19^{\circ} 27^{\prime} 47^{\prime \prime S}$ & $43^{\circ} 33^{\prime} 10^{\prime \prime} \mathrm{W}$ & 34,739 \\
\hline Lippia lacunosa Mart. \& Schauer & Diamantina-MG & $18^{\circ} 14^{\prime} 48^{\prime \prime S}$ & $43^{\circ} 36^{\prime} 6^{\prime \prime} \mathrm{W}$ & 42,705 \\
\hline Lippia lupulina Cham. & Diamantina-MG & $18^{\circ} 14^{\prime} 48^{\prime \prime S}$ & $43^{\circ} 36^{\prime} 6^{\prime \prime} \mathrm{W}$ & 34,742 \\
\hline Lippia pohliana Schauer & Diamantina-MG & $18^{\circ} 14^{\prime} 48^{\prime \prime S}$ & $43^{\circ} 36^{\prime} 6^{\prime \prime} \mathrm{W}$ & 39,360 \\
\hline Lippia pseudothea (St. Hil) Schauer & Diamantina-MG & $18^{\circ} 14^{\prime} 48^{\prime \prime S}$ & $43^{\circ} 36^{\prime} 6^{\prime \prime} \mathrm{W}$ & 34,340 \\
\hline Lippia rosella Moldenke & Diamantina-MG & $18^{\circ} 14^{\prime} 48^{\prime \prime S}$ & $43^{\circ} 36^{\prime} 6^{\prime \prime} \mathrm{W}$ & 34,746 \\
\hline Lippia rotundifolia Cham. & Diamantina-MG & $18^{\circ} 14^{\prime} 48^{\prime \prime} \mathrm{S}$ & $43^{\circ} 36^{\prime} 6^{\prime \prime} \mathrm{W}$ & 34,338 \\
\hline Lippia rubella Moldenke & Diamantina-MG & $18^{\circ} 14^{\prime} 48^{\prime \prime S}$ & $43^{\circ} 36^{\prime} 6^{\prime \prime} \mathrm{W}$ & 42,706 \\
\hline Lippia sidoides Cham. & Serra do Cipó-MG & $19^{\circ} 27^{\prime} 47^{\prime \prime} \mathrm{S}$ & $43^{\circ} 33^{\prime} 10^{\prime \prime} \mathrm{W}$ & 34,737 \\
\hline
\end{tabular}

[ $4 \%$ cellulase (Sigma) plus $40 \%$ pectinase (Sigma) diluted in $0.001 \mathrm{M}$ citric acid-sodium citrate $\mathrm{pH}$ 4.8 buffer] at $37^{\circ} \mathrm{C}(4 \mathrm{~h})$. The slides were prepared according to Carvalho and Saraiva $(1993,1997)$.

Slide preparation (buds meristems). Due great difficulty in the obtaining of root meristem in some species of Lippia (L. lacunosa, L. pseudothea, and L. diamantinensis), bud meristems were also used for chromosome achievement. The slides were prepared according to Viccini et al. (2006) with some modifications. Nearly ten pre-treated meristematic apical buds were placed in a $0.5 \mathrm{~mL}$ microtube adapted with a $60 \mu \mathrm{m}$ nylon mesh. The material was washed three times in distilled water to remove fixative solution. The adapted tube containing the apical buds meristems was immersed in another normal microtube $(1.5 \mathrm{~mL})$ with concentrated enzymatic solution (Pectinex NOVO FERMENT ${ }^{\mathrm{TM}}$ ). The material was placed in an incubator at $34^{\circ} \mathrm{C}$ for $20 \mathrm{~min}$. After enzymatic maceration, the material was washed again in order to remove the excess of enzymatic solution. The adapted microtube was then placed into another microtube $(1.5 \mathrm{~mL})$ containing distilled water. The meristems were mechanically fragmented with an adapted pin in order to permit the dissociation of the tissue. The cellular suspension obtained was then centrifuged three times at 2,000 rpm for $12 \mathrm{~min}$. In each step, the supernatant was removed and the volume of the microtube was completed with distilled water. After the last centrifugation, the volume of the microtube was replenished with fresh fix. The cellular suspension was carefully resuspended. The final suspension was stored at $-20^{\circ} \mathrm{C}$. For slide preparation, about six drops of the suspension were dropped onto a clean slide. The slides were air-dried and stained with Giemsa solution (5\%) for $3 \mathrm{~min}$.

Karyotype analysis. At least five metaphases by individual were used to determine the length of the short (si) and long arm (li) of each chromosome (i). The chromosome length $(t=l i+s i)$ and arm ratio $(r=l i / s i)$ were calculated. The chromosomes were classified on the basis of arm ratio using the standard nomenclature (Levan et al. 1964): m: median ( $r=1.01$ 1.69); sm: submedian ( $\mathrm{r}=1.70-3.00)$; st: subterminal $(r=3.01-7.00)$; and t: terminal $(r=7.01-8.00)$.

Karyotype asymmetry, the length of heterogeneity or degree of asymmetry of each chromosome $(A i)$ and the degree of karyotype asymmetry $(A)$ were estimated as proposed by Watanabe et al. (1999): 


$$
A i=(l i-s i) /(l i+s i) \text { and } A=(1 / \mathrm{n}) \Sigma A i
$$

where $n$ is the haploid chromosome number with $A$ ranges from zero (completely symmetrical) to one (completely asymmetrical).

Chromosomes were measured using Image ProPlus software (Media Cybernetics ${ }^{\mathrm{TM}}$ ) and the ideograms arranged in order of decreasing short arm length.
RESULTS

\section{KARYOTYPE CONSTITUTION}

The karyotypic constitution of Lippia species was highly variable between the 12 species studied (Fig. 1). In general, Lippia karyotypes have mainly median and submedian chromosomes. Only L. diamantinensis $(2 \mathrm{n}=52)$ and L. lacunosa $(2 \mathrm{n}=56)$ showed chromosomes with sub-terminal
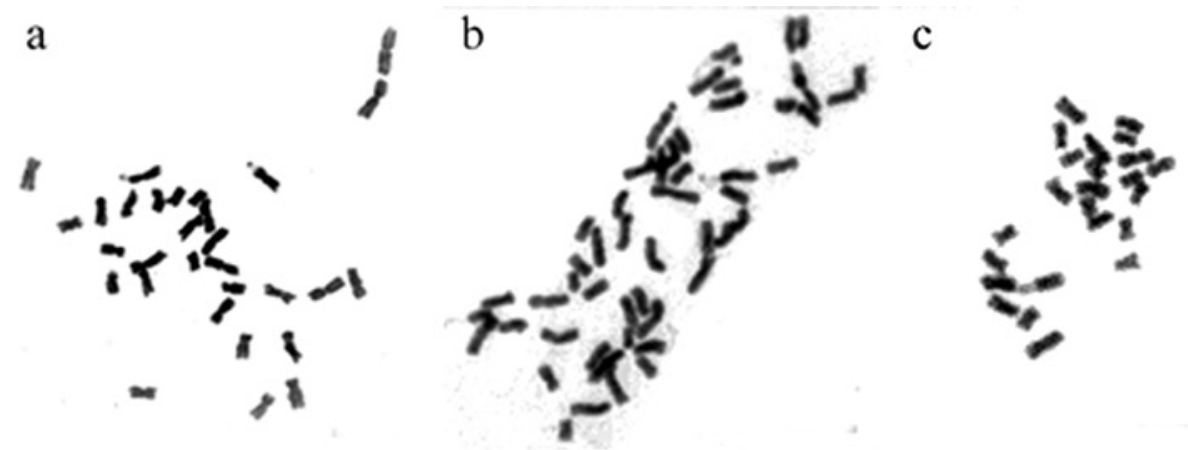

d
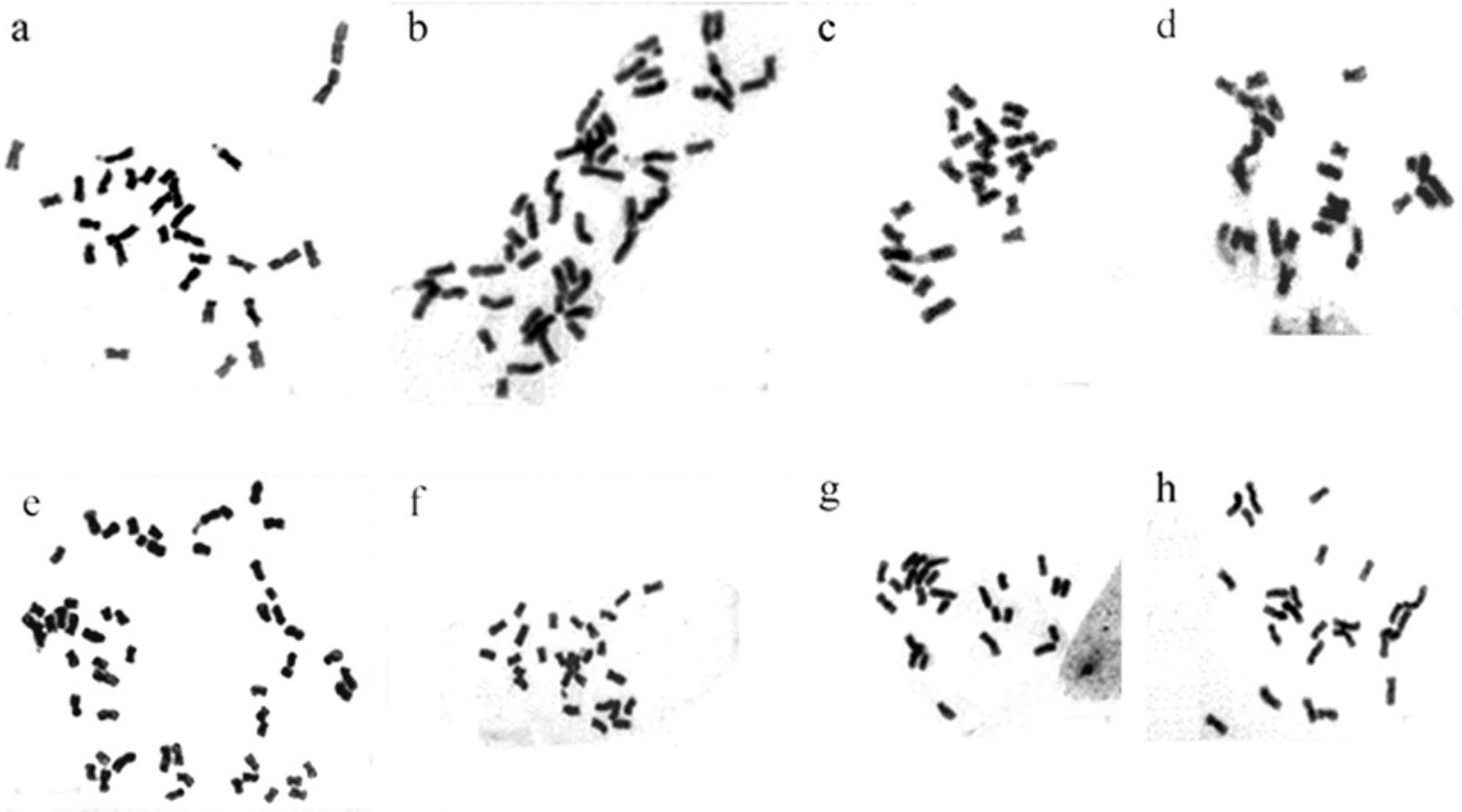

f

$\mathrm{g}$
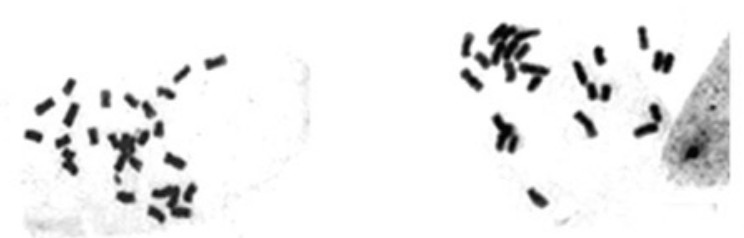

h 사
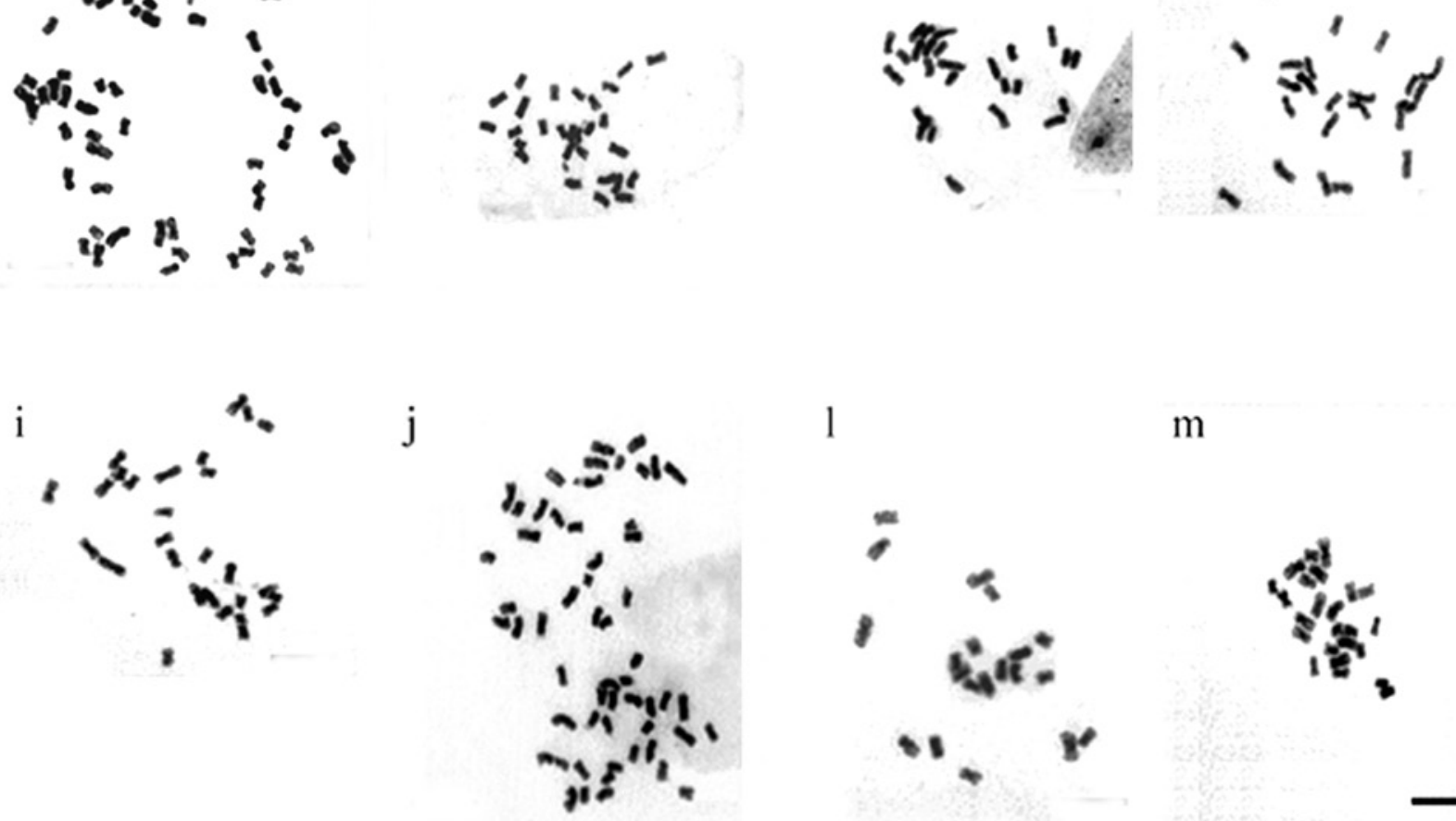

1

$\mathrm{m}$
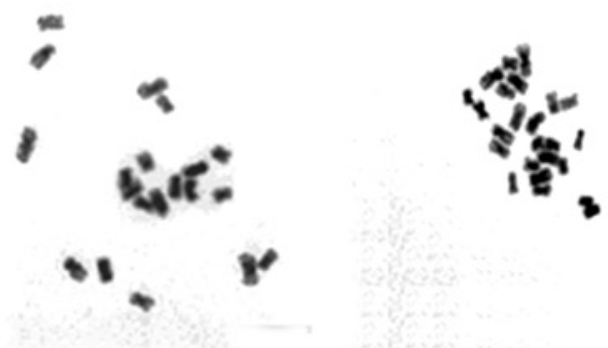

Fig. 1 - Metaphase chromosomes of (a) L. alba, $2 \mathrm{n}=30$; (b) L. diamantinensis, $2 \mathrm{n}=52$; (c) L. florida, $2 \mathrm{n}=24$; (d) L. hermanioides, $2 \mathrm{n}=26$; (e) L. lacunosa, $2 \mathrm{n}=56$; (f) L. lupulina, $2 \mathrm{n}=28$; (g) L. pohliana, $2 \mathrm{n}=24$; (h) L. pseudothea, $2 \mathrm{n}=26$; (i) L. rosella, $2 \mathrm{n}=28 ;$ (j) L. rotundifolia, $2 \mathrm{n}=56$; (l) L. rubella, $2 \mathrm{n}=20$; and (m) L. sidoides, $2 \mathrm{n}=24$;. Bars $=5 \mu \mathrm{m}$. 
centromers. The percentage of median chromosomes varied from $42 \%$ in L. diamantinensis $(2 \mathrm{n}=52)$ to $100 \%$ in L. rubella $(2 \mathrm{n}=20)$ (Table II).

\section{Chromosome LeNGTH}

The chromosome length of those twelve Lippia species was relatively small, with $L$. diamantinensis showing the smallest and the bigger chromosomes, ranging from $0.42 \mu \mathrm{m}$ to $2.47 \mu \mathrm{m}$ (Table II). A direct relationship between the average of chromosome length and the chromosome number was not observed. Nevertheless, the total chromosome length (TCL) increase as the chromosome number increased (Fig. 2a). The TCL varied from 16.96 in L. rubella to $67.96 \mu \mathrm{m}$ in $L$. diamantinensis and the average of TCL of all species was $37.40 \mu \mathrm{m}$ (Table II).

KARYOTYPE ASYMMETRY

As the degree of asymmetry $(A)$ increased, the chromosome number increased accordingly (Fig. 2b). Species with chromosome number smaller than $2 \mathrm{n}=30$ showed an asymmetry $(A)$ ranging from 0.09 in L. rubella $(2 \mathrm{n}=10)$ to 0.15 in L. alba $(2 \mathrm{n}=30)$, while species with higher chromosome number showed values varying from 0.21 to 0.26. L. diamantinensis karyotype was the most asymmetric one (Table II).

\section{SECONDARY CONSTRICTIONS}

Six species exhibit secondary constrictions (SC): $L$. alba, L. florida, L. hermanioides, L. diamantinensis, L. lacunosa and L. rotundifolia. The number of SC varied among the species, ranging from one pair in L. hermanioides, L. florida and L. lupulina to four in L. diamantinensis. Moreover, the positions of SC varied among the species. Some of them showed this structure only in the short chromosome arms while others showed the same structure in both arms (Fig. 3).

\section{DISCUSSION}

Previous cytogenetic studies in the genus Lippia indicated that the genus has a wide range of chromosome numbers: $2 \mathrm{n}=20,24,26,28,30$, 32, 52 and 56 (Viccini et al. 2006, Campos et al. 2011). The present study confirmed the previous chromosome numbers (Viccini et al. 2006, Bose and Choudhury 1960) for all species that were now investigated by mitotic chromosomes.

TABLE II

Karyotype characters of 12 Lippia species. Abbreviations: $2 \mathrm{n}=$ chromosome number; $\mathrm{PMC}=$ percentage of median chromosomes; $T C L=$ total chromosome length; $A C L=$ average chromosome length $\mathbf{L C L}=$ longest chromosome length; SCL = shortest chromosome length; $A=$ Karyotype asymmetry; KF = karyotype formulae.

\begin{tabular}{lcccccccc}
\hline Taxon & $2 \mathrm{n}$ & PMC $(\%)$ & TCL $(\mu \mathrm{m})$ & ACL $(\mu \mathrm{m})$ & LCL $(\mu \mathrm{m})$ & SCL $(\mu \mathrm{m})$ & $A$ & KF \\
\hline L. rubella & 20 & 100 & 16.96 & 1.54 & 1.36 & 0.43 & 0.09 & $10 \mathrm{~m}$ \\
L. pohliana & 24 & 75 & 19.78 & 0.82 & 1.54 & 0.44 & 0.12 & $9 \mathrm{~m}+3 \mathrm{sm}$ \\
L. florida & 24 & 75 & 24.26 & 1.01 & 1.54 & 0.51 & 0.12 & $9 \mathrm{~m}+3 \mathrm{sm}$ \\
L. sidoides & 24 & 92 & 26.40 & 1.10 & 1.41 & 0.58 & 0.11 & $11 \mathrm{~m}+1 \mathrm{sm}$ \\
L. hermanioides & 26 & 77 & 29.70 & 1.14 & 1.48 & 0.72 & 0.12 & $10 \mathrm{~m}+3 \mathrm{sm}$ \\
L. pseudothea & 26 & 62 & 38.70 & 1.49 & 2.00 & 1.03 & 0.14 & $8 \mathrm{~m}+5 \mathrm{sm}$ \\
L. lupulina & 28 & 71 & 28.00 & 1.00 & 1.52 & 0.66 & 0.14 & $10 \mathrm{~m}+4 \mathrm{sm}$ \\
L. rosella & 28 & 72 & 33.22 & 1.19 & 1.95 & 0.51 & 0.15 & $11 \mathrm{~m}+3 \mathrm{sm}$ \\
L. alba & 30 & 67 & 34.00 & 1.13 & 2.01 & 0.48 & 0.15 & $10 \mathrm{~m}+5 \mathrm{sm}$ \\
L. diamantinensis & 52 & 42 & 67.96 & 1.31 & 2.47 & 0.42 & 0.26 & $11 \mathrm{~m}+13 \mathrm{sm}+2 \mathrm{st}$ \\
L. lacunosa & 56 & 64 & 62.28 & 1.11 & 1.78 & 0.43 & 0.21 & $18 \mathrm{~m}+7 \mathrm{sm}+3 \mathrm{st}$ \\
L. rotundifolia & 56 & 50 & 67.56 & 1.20 & 1.83 & 0.46 & 0.22 & $14 \mathrm{~m}+14 \mathrm{sm}$ \\
\hline
\end{tabular}



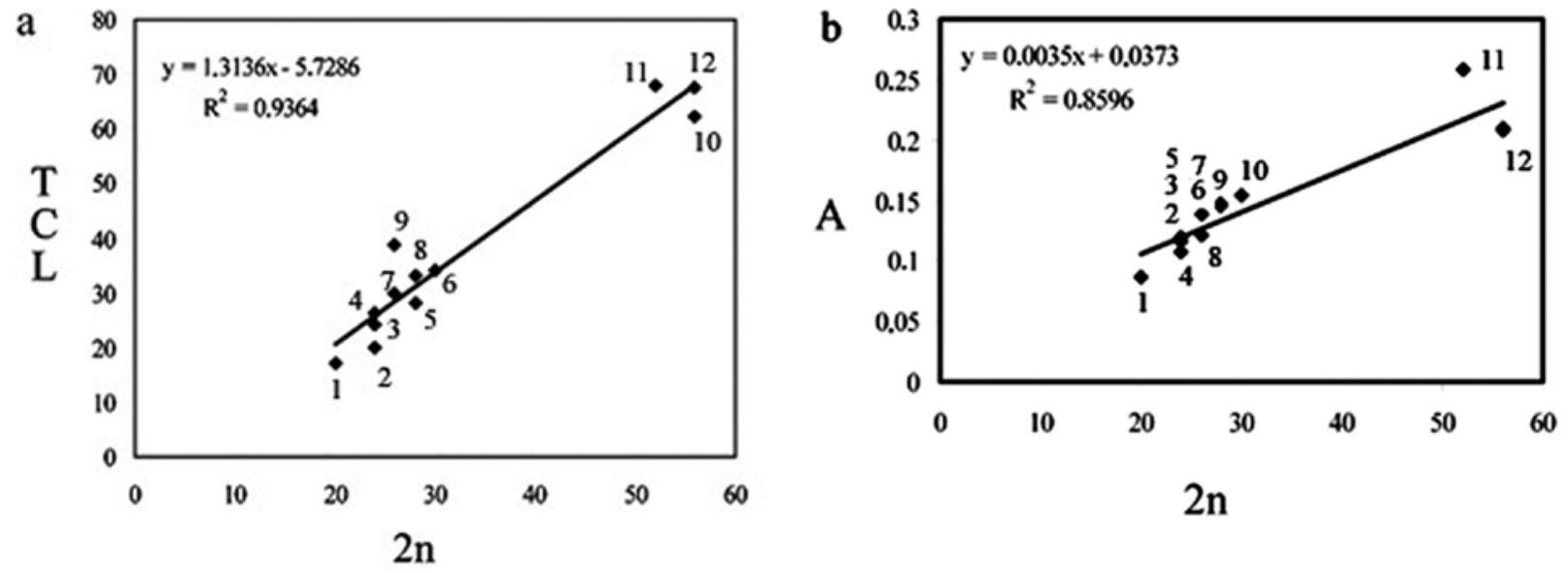

Fig. 2 - (a) Relationship between total chromosome length (TCL) and chromosome number. (b) Relationship between asymmetry (A) and the chromosome number. (1) L. rubella, (2) L. pohliana, (3) L. florida, (4) L. sidoides, (5) L. hermanioides, (6) L.pseudothea, (7) L. lupulina, (8) L. rosella, (9) L. alba, (10) L.diamantinensis, (11) L. lacunosa, (12) L. rotundifolia.

Regarding karyomorphological aspects, symmetrical karyotypes have been considered as less derived and asymmetrical karyotypes as the more derived ones (Stebbins 1971). The present data revealed that asymmetry of Lippia karyotypes increase as the chromosome number increase, suggesting that an increment of the chromosome number constitutes an important factor in the evolution of Lippia chromosomes.

According to Sanders (2001), the hypothesis of $\mathrm{x}=5$ as an ancestral chromosome number for the family Verbenaceae seems to be the most reasonable. According to the same author, the numbers $\mathrm{x}=6$ and 7 could have arisen by ascending aneuploidy and $\mathrm{x}=10$ by polyploidy, which, by descending aneuploidy, could have originated the numbers $\mathrm{x}=9$ and 8. Viccini et al. (2006) suggested two mechanisms for karyotypic evolution within the genus Lippia: polyploidy and aneuploidy. Although Lippia species with $\mathrm{n}=5$ have not been described, Campos et al. (2011) suggested that an ancestral species with $2 n=10$ could rise species with $2 n=$ 20 (by chromosome duplication, autopolyploidy), which could have originated numbers $2 \mathrm{n}=16$ and 18 through descending dysploidy. Additionally, ascending dysploidy could be responsible for the origin of $2 n=12$ and $2 n=14$, from which chromosome duplication could lead to $2 \mathrm{n}=24$ and $2 \mathrm{n}=28$, respectivelly. The species with $2 \mathrm{n}=$ 26 and $2 n=30$ could have arisen by hybridization between species with $2 \mathrm{n}=12$ and 14 or $2 \mathrm{n}=18$ and $2 \mathrm{n}=16$, respectively, followed by genome duplication. Species with $2 n=52$ and $2 n=56$ could be formed from another event of autopolyploidy or allopolyploidy. Here we observed differences among average length of Lippia chromosomes in addition to variation in the centromer position, in the number and position of secondary constriction and also an increase of total chromosome length (mainly due to polyploidy). Dysploidy plus polyploidy can be considered the most important events in chromosome evolution of several plant groups (James 1981, Otto and Whitton 2000, Guerra 2008). Although the descending dysploidy series is more common (Stebbins 1971, Levin 2002, Guerra 2008), some groups show an ascending series as described in Hemizonia (Asteraceae) (Kyhos et al. 1990), Gentiana (Gentianaceae) (Yuan et al. 1998), Sideritis (Lamiaceae) (Barber et al. 2000), and in Exacum (Gentianaceae), Ornichia (Gentianaceae), Sebaea (Gentianaceae) and Tachiadenus (Gentianaceae) (Kissling et al. 2008). The same fact was here 
Lippia alba

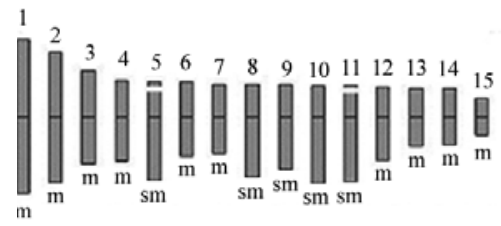

Lippia florida

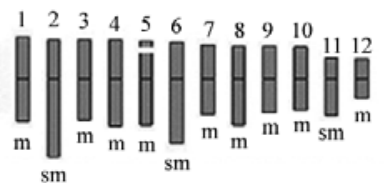

Lippia hermanioides

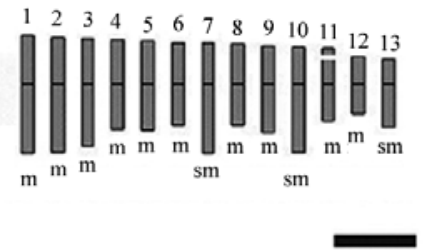

Lippia diamantinensis

Lippia lupulina
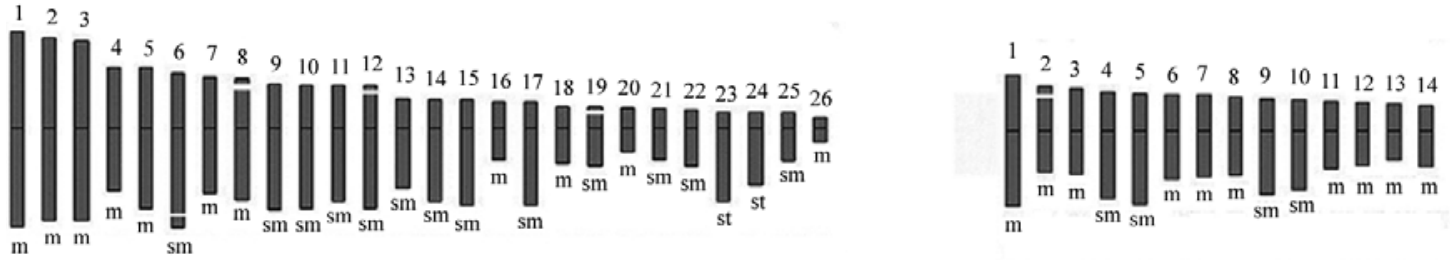

Lippia pohliana

Lippia pseudothea

Lippia rosella
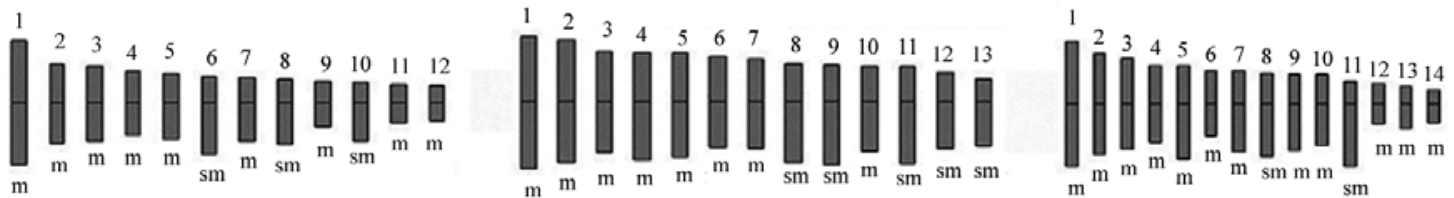

Lippia rubella

Lippia sidoides
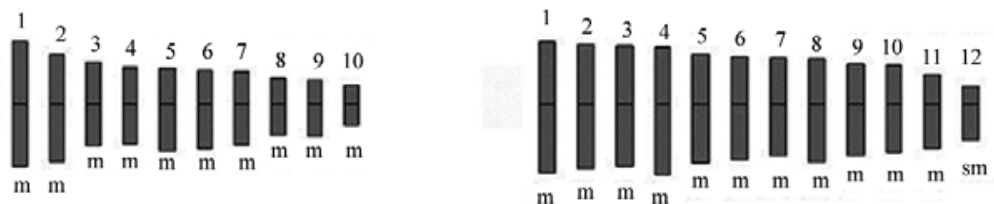

$m \mathrm{~m} m$

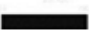

Lippia lacunosa

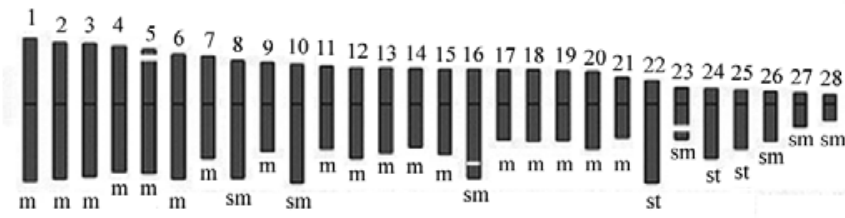

Lippia rotundifolia

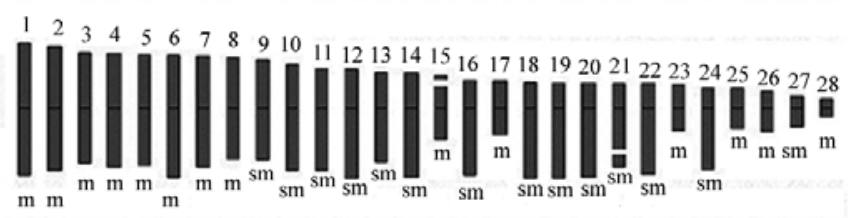

Fig. 3 - Haploid idiograms of 12 Lippia species. Bars $=1 \mu \mathrm{m}$. 
observed and seems to be the same case in the genus Lippia. Our data reinforce the hypothesis proposed by Campos et al. (2011), that dysploidy followed by polyploidy could be the most important mechanisms of Lippia chromosome evolution.

Taxonomically, according to Troncoso (1974), the Brazilian Lippia species are divided in five sections: Dipterocalyx, Goniostachyum, Zapania, Rhodolippia, Pseudoaloysia and Dioicollipia. In our study L. rubella, L. hermanioides, L. alba, L. diamantinensis, $L$. lacunosa and $L$. rotundifolia belong to Zapania section; L. florida, L. pseudothea, L. lupulina and L. rosella belong to Rhodolippia section; while only L. pohliana and $L$. sidoides belong to Goniostachyum section. According to our analysis, the section Zapania is the most variable regarding chromosome number and size. Moreover, this is the unique section where we observed secondary constrictions in both chromosome arms, while in the other sections this structure were observed only in the short arm of the chromosomes. According to Campos et al. (2011), Viccini et al. (2006) and Salimena (2000), the Zapania section should be reappraised considering the higher variation in chromosome number, DNA content and plant morphology. The variation in chromosome size and position of the secondary constriction among species here observed reinforce that suggestion.

Regarding the absence of secondary constrictions in some species, these structures are formed in active sites with 45S rDNA (NORs) and sites with restricted NOR activation can, but do not have to form secondary constrictions, thus hindering the real determination of their number and position through conventional techniques (Marcon et al. 2005). For this, the application of FISH and AgNOR banding (two more refined techniques for NOR visualization) in the species where secondary constriction were not observed. It will be very important in the future for a better knowledge of the distribution of these structures among the species studied here, as well as their activity in the precedent interphases.
The present data constitutes the first karyomorphological study for eleven of twelve species here investigated, and were important to corroborate previous hypothesis and to reveal new aspects of Lippia chromosomes, especially mitotic ones. Nevertheless, additional studies including more species and integrating karyology, phylogeny, distribution, specific divergence time, geographical and climatics changes would be desirable in order to extend our conclusions and consequently better understand the evolution of the genus.

\section{RESUMO}

O gênero Lippia (Verbenaceae) possui cerca de 160 espécies distribuídas principalmente nas Américas Central e do Sul com poucas espécies Africanas, algumas delas com potencial uso medicinal. O Brasil é um dos mais importantes centros de diversidade com aproximadamente $75 \%$ das espécies descritas. Inúmeras espécies são endêmicas e pouco estudadas, principalmente a nível citológico. Aqui, o comprimento cromossômico, a cariomorfologia e a assimetria cromossômica de doze espécies brasileiras de Lippia foram avaliados [L. alba (Miller) N.E.Brown, $L$. diamantinensis Glaz., L. florida Cham., L. hermanioides Cham., L. lacunosa Mart. \& Schauer, L. lupulina Cham., L. pohliana Schauer, L. pseudothea (St. Hil) Schauer, L. rosella Moldenke, L. rotundifolia Cham., L. rubella Moldenke e L. sidoides Cham.]. As análises sugeriram que o gênero tem um número cromossômico variável (de $2 n=$ 20 a $2 n=56$ ) originado por disploidia e poliploidia. Esta é a primeira descrição da morfologia cromossômica para 11 das 12 espécies de Lippia estudadas.

Palavras-chave: cromossomos, citologia, disploidia, cariologia, Lippia, poliploidia.

\section{ACKNOWLEDGMENTS}

The authors thank the Fundação de Amparo à Pesquisa do Estado de Minas Gerais (FAPEMIG), Conselho Nacional de Desenvolvimento Científico e Tecnológico (CNPq) and Coordenação de Aperfeiçoamento de Pessoal de Nível Superior (CAPES) for the financial support. 


\section{REFERENCES}

BArber JC, Ortega FJ, Guerra AS, Marrero A AND JANSEN RK. 2000. Evolution of endemic Sideritis (Lamiaceae) in Macaronesia: insights from a chloroplast DNA restriction site analysis. Syst Bot 25: 633-647.

Bose RB AND CHOUdHuRY JK. 1960. Cytological studies in L. alba (Mill) N. E. Br. Bull Bot Soc Bengal 14: 71-72.

BRANDÃo AD, VICCINI LF AND RECCO-PIMENTEL SM. 2005. Meiotic analysis of two putative polyploidy specie of Verbenaceae from Brazil. Caryologia 4: 315-319.

BRANDÃo AD, ViCCINI LF, SALIMENA FRG, VANZELA ALL AND RECCO-PIMENTEL SM. 2007. Cytogenetic characterization of Lippia alba and Lantana camara (Verbenaceae) from Brazil. J Plant Res 120: 317-321.

CAMPos JMS, SOUSA SM, SILVA PS, PINHEIRO LC, SAMPAIO F AND VICCINI LF. 2011. Chromosome numbers and DNA C values in the genus Lippia (Verbenaceae). Plant Syst Evol 291: 133-140.

CARVALHO CR AND SARAIVA LS. 1993. A new heterochromatin banding pattern revealed by modified HKG banding technique for maize chromosomes. Heredity 70: 515-519.

CARVALHO CR AND SARAIVA LS. 1997. High- resolution HKGbanding in maize mitotic chromosomes. J Plant Res 110: 417-420

COLEMAN JR. 1982. Chromosome numbers of angiosperms collected in the state of São Paulo. Rev Bras Genet 3: 533-549.

FILIPPA EM. 1984. El numero cromossomico de L. turbinata (Verbenaceae). Kurtziana 17: 169-170.

GUERRA M. 2008. Chromosome numbers in plant cytotaxonomy: concepts and implications. Cytogenet Genome Res 120: 339-350.

JAMES SH. 1981. Cytoevolutionary patterns, genetic systems and phytogeography of Australian. In: Keast A., ed. Ecological biogeography of Australia. Hague: Dr W. Junk, p. 763-784.

JONES K. 1998. Robertsonian fusion and centric fission in karyotype evolution of higher plants. Bot Rev 64: 273-289.

Kissling J, Zeltner L, Kupfer P And Mansion G. 2008. Cytogeography of Gentianaceae-Exaceae in Africa, with a special focus on Sebaea: the possible role of dysploidy and polyploidy in the evolution of the tribe. Bot J Linn Soc 58: 556-566.

Kumar P AND DutT B. 1989. Cytogenetic basis of breeding system in some verbenaceous species. Cytologia 54: 347-353.

KYHOS DW, CARR GD AND BALDWIN BG. 1990. Biodiversity and cytogenetics of the tarweeds (Asteraceae: HeliantheaeMadiinae). Ann Mo Bot Gard 77: 84-95.

Levan A, Fredga A And Sanderberg AA. 1964. Nomenture for centromeric position in chromosomes. Hereditas 52: 201-220.

LEVIN DA. 2002. The role of chromosomal change in plant evolution. Oxford University Press, New York, New York, USA.

MARCON AB, BARROS ICL AND GUERRA M. 2005. Variation in Chromosome Numbers, CMA Bands and 45S rDNA Sites in Species of Selaginella (Pteridophyta). Ann Bot 95: 271-276.
NAVANEETHAN N. 1982. Karyomorphological studies in two species of Cryptolepis R. Br. Proc. Indian Sci Congr Assoc 69: 231-232.

Otto SP AND Whitton J. 2000. Polyploid Incidence and Evolution. Annu Rev Genet 34: 401-437.

Pascual ME, Slowing K, CARRetero E, SÁnchez MD AND VILLAR A. 2001. Lippia: traditional uses, chemistry and pharmacology: a review. J Ethnopharmacol 6: 201-214.

PASTORIZA AV AND ANDRADA AB. 2006. Cytogenetics in Lippia species (Verbenaceae) from northwest Argentina. BAG J Basic Appl Genet 17: 25-32.

Pellicer J, Garcia S, Garnatje T, Hidalgo O, Korobkov AA, DARIIMAa S AND VAllès J. 2007. Chromosome counts in Asian Artemisia L. (Asteraceae) species: from diploids to the first report of the highest polyploid in the genus. Bot J Linn Soc 153: 301-310.

Pierre PMO, Sousa SM, Davide LC, Machado MA AND VICCINI LF. 2011. Karyotype analysis, DNA content and molecular screening in Lippia alba (Verbenaceae). An Acad Bras Cienc 83: 993-1005.

RAMSEY JR AND SCHEMSKE DW. 1998. Pathways, mechanisms, and rates of polyploid formation in flowering plants. Annu Rev Ecol Syst 29: 467-501.

SALIMENA FRG. 2000. Revisão taxonômica de Lippia L. sect. Rhodolippia Schauer (Verbenaceae). D. Sc. Thesis. Universidade de São Paulo, São Paulo, Brazil.

SANDERS RW. 2001. The genera of Verbenaceae in the southeastern United States. Harv Pap Bot 5: 303-358.

SMITH EB. 1966. Cytogenetics and phylogeny of Haplopappus section Isopappus (Compositae). Can J Genet Cytol 18 : 14-36.

Soltis DE, Albert VA, LeEbEns-Mack J, Bell CD, PATERSon AH, Zheng C, SANKofF D, Depanphilis CW, WALL PK AND SOLTIS PS. 2009. Polyploidy and angiosperm diversification. Am J Bot 96: 336-348.

Sousa SM, Silva PS, TORRES GA AND Viccini LF. 2009. Chromosome banding and essential oils composition of Brazilian accessions of Lippia (Verbenaceae). Biologia 64: 711-715.

SteBbins GL. 1971. Chromosomal evolution in higher plants. London: Edward Arnold.

Troncoso NS. 1974. Los géneros de Verbenaceas de Sudamerica extra-tropical (Argentina, Chile, Bolívia, Paraguay, Uruguay y sur de Brasil). Darwiniana 18: 295-412.

Viccini LF, PierRe PMO, PraÇa MM, Costa DCS, RomANel EC, Sousa SM, PeiXoto PHP AND SALIMENA FRG. 2006. Chromosome numbers in the genus Lippia (Verbenaceae). Plant Syst Evol 256: 171-178.

Watanabe K, Yahara T, Denda T And Konsuge K. 1999. Chromosomal evolution in the genus Brachyscome (Asteraceae, Astereae): Statistical tests regarding correlation between changes in karyotype and habit using phylogenetic information. J Plankton Res 112: 145-161.

YUAN YM, KUPFER P AND ZELTNER L. 1998. Chromosomal evolution of Gentiana and Jaeschkea (Gentianaceae), with further documentation of chromosome data for 35 species from western China. Plant Syst Evol 210: 231-247. 